\title{
Influence of Phosphorus Application with Avail on Following Soybeans in Southeastern Coastal Plains
}

\author{
Pawel Wiatrak \\ School of Agricultural, Forest and Environmental Sciences, \\ Clemson University, Edisto REC, Blackville, USA
}

Received 2013-10-11, Revised 2013-10-24; Accepted 2013-10-25

\begin{abstract}
Application of Phosphorus (P) in combination of with polymer Avail to previous crop may affect soybeans [Glycine $\max$ (L.) Merr.] under dryland conditions. The objective of this study was to determine the effect of two $\mathrm{P}$ rates ( 45 and $90 \mathrm{~kg} \mathrm{P}_{2} \mathrm{O}_{5} \mathrm{ha}^{-1}$ ) with and without Avail applied to winter wheat (Triticum aestivum L.) previous crop on growth and yields of dryland soybeans near Blackville, SC from 2011 to 2012. Soybeans were evaluated for Leaf Area Index (LAI), plant Normalized Difference Vegetation Index (NDVI), plant height, grain moisture, seed weight and grain yields. Compared to untreated control, $\mathrm{P}$ applications at $45 \mathrm{~kg}$ and $90 \mathrm{~kg} \mathrm{ha}^{-1}$ with Avail to winter wheat significantly increased soybean grain yields by $12.3 \%$ and $20.2 \%$, respectively. Phosphorus applied to previous crop at $45 \mathrm{~kg}$ and $90 \mathrm{~kg} \mathrm{P}^{-1}{ }^{-1}$ with polymer Avail, improved soybean yields by 8.1 and $4.0 \%$ over $\mathrm{P}$ treatments not treated with Avail, respectively. Soybean LAI significantly increased by $22.8 \%$ at 3 months after planting with application of $\mathrm{P}$ at $90 \mathrm{~kg} \mathrm{ha}^{-1}$ and polymer Avail to winter wheat previous crop compared to untreated control. Lower P rate of $45 \mathrm{~kg} \mathrm{ha}^{-1}$ with Avail to winter wheat increased soybean LAI by $11.8 \%$. Applications of $45 \mathrm{~kg}$ and $90 \mathrm{~kg}$ $\mathrm{P} \mathrm{ha}^{-1}$ with Avail to previous crop improved plant NDVI at 3 months after soybean planting by $1.8 \%$ and $2.5 \%$, respectively. Based on significant linear relationship, increasing plant NDVI by 0.1 improved soybean yields by $126.1 \mathrm{~kg} \mathrm{ha}^{-1}$. Applications of $\mathrm{P}$ with Avail to winter wheat did not affect soybean LAI and NDVI at 2 months after planting, plant height, grain moisture and seed weight. Results from this study indicate that $\mathrm{P}$ applications with Avail to previous crop significantly improved plant LAI and NDVI at 3 months after planting and increased soybean yields.
\end{abstract}

Keywords: Soybean, Polymer, Avail, Phosphorus, Normalized Difference Vegetation Index (NDVI), Leaf Area Index (LAI)

\section{INTRODUCTION}

Reduced yield potential of soybeans is a result of low soil Phosphorus (P) (Liu et al., 2010) and insufficient water availability (Zheng et al., 2010). Many areas in the World are deficient in available P (McLaughlin et al., 2011). Improved soybean yields have been shown with improved nodulation after $\mathrm{P}$ application and Rhizobium inoculation (Abbasi et al., 2010 ) and with $P$ and potassium (K) applications, which also improved seed protein content (Abbasi et al., 2012). Phosphorus fertilization was effective in reducing the impact of drought and therefore improving yields in studies conducted by Zheng et al. (2010).
Fertilizer recommendations depend on determination of nutrients supplied and immobilized in the soil, which is very important for a site-specific nutrient management (Anthony et al., 2012). Qiao (2012) pointed out that soil $\mathrm{P}$ distribution is essential to improve nutrient uptake. McBeath et al. (2012) indicated that most $P$ available to plants was in the topsoil, but adding P improved uptake of nutrient from the subsoil. They also reported that $\mathrm{P}$ fertilizer applied below seeds increased nutrient uptake from the subsoil. According to McBeath et al. (2011), P should be applied at early stages of crop growth. Compared to untreated control, applying P fertilizer near seeds increased plant weight, nutrient uptake and content in plants, therefore placing fertilizer close to seeds 
should be a recommended management practice in crop production (Rehm and Lamb, 2010).

Phosphorus availability is not only affected by nutrient management, but also cropping system (Nunes et al., 2011), which can help with the sustainability of agricultural production (Steiner et al., 2012). Phosphorus in plant residues from previous crop may be utilized by following crops (Noack et al., 2012). Under no-till system, $P$ released from plant residues and concentrated in the soil surface helps to improve nutrient availability of following crops (Olibone and Rosolem, 2010). Hassan et al. (2012) noted that $\mathrm{P}$ uptake improved in cereal crops following legumes. Continued cereal systems required $\mathrm{P}$ application every other year, while after soybean $\mathrm{P}$ was required in one out of three years in studies conducted by Kihara et al. (2010).

Alternative fertilization may help to reduce nutrient loss, especially in sandy soils subjected to nutrient leaching (Yang et al., 2012). Using technologies to improve $\mathrm{P}$ efficiency is a good alternative in crop production (De Figueiredo et al., 2012). According to McLaughlin et al. (2011), slow release $\mathrm{P}$ products improve nutrient use efficiency in soils with leaching problems. They also indicated that soil $\mathrm{P}$ placement is important in improving $\mathrm{P}$ use efficiency. Guareschi et al. (2011) reported that soybean yields increased with superphosphate coated polymer applied at 15 days prior to planting; however, there was no significant difference between coated and uncoated fertilizer application at planting.

Little research focused on the effect of $P$ coated with polymer Avail applied to previous crop on following soybean crop under insufficient rainfall. McLaughlin et al. (2011) indicated that $\mathrm{P}$ use efficiency is generally low in first year and residual effect is important for the following crop. Moreover, polymer-coated fertilizer should be evaluated for improving nutrient efficiency (De Figueiredo et al., 2012). Therefore, objective of this study was to evaluate polymer coated $\mathrm{P}$ applied to winter wheat previous crop on soybeans under dryland conditions in Southeastern Coastal Plains.

\section{MATERIALS AND METHODS}

\subsection{Site Preparation and Management}

This study was conducted on Faceville loamy sand (Fine, kaolinitic, thermic Typic Kandiudults) at Clemson University, Edisto Research and Education Center (REC) near Blackville, SC $\left(33^{\circ} 21^{\prime} \mathrm{N}, 81^{\circ} 18^{\prime}\right.$ W) under dryland conditions in 2011 and 2012. These are well drained soils with moderate permeability and soil $\mathrm{pH}$ was 6.6. Treatments consisted of 2 rates of $\mathrm{P}$
(45 and $90 \mathrm{~kg} \mathrm{P}_{2} \mathrm{O}_{5} \mathrm{ha}^{-1}$ ) with and without Avail applied to winter wheat previous crop and an untreated control.

Prior to planting winter wheat previous crop, all treatments with Diammonium Phosphate (DAP) (1846-0 of N-P $\mathrm{P}_{2} \mathrm{O}_{5}-\mathrm{K}_{2} \mathrm{O}$ fertilizer with and without Avail) were applied separately in each plot using a handheld spreader. Soybean cv. 'Pioneer 97M50' was planted after harvest of winter wheat at 272,000 seeds $\mathrm{ha}^{-1}$ in strip-till using Univerferth Ripper-Stripper (Unverferth Mtg. Co., Inc., Falida, OH) implement and John Deere 1700 MaxEmerge XP vacuum planters (John Deere Co., Moline, IL) on 27 May 2011 and 13 June 2012. The plot size was $9.1 \mathrm{~m}$ long by $4.0 \mathrm{~m}$ wide with four soybean rows. Pest control was based on the South Carolina Extension recommendations.

\subsection{Plant Measurements}

Plant measurements were conducted in the center of each plot. Normalized Difference Vegetation Index (NDVI) was measured using handheld GreenSeeker ${ }^{\mathrm{TM}}$ (NTech Industries, Inc. Ukiah, CA) instrument and the Leaf Area Index (LAI) LAI-2000 (Li-Cor, Lincoln, $\mathrm{NE}$ ) meter was used to measure plant index at 8 and 12 weeks after soybean planting. Ten random plants were selected for height measurements from the ground to the top of the plant prior to soybean harvest.

Soybeans were harvested from the entire length of plot using Kinkaid 8XP small plot combine (Kinkaid Equip. Mtg, Haven, KS) on 8 November 2011 and 29 October 2012. Grain samples from all harvested plots were evaluated for weight and tested for moisture content using a Burrows Model 750 Digital Moisture Computer (Seedburo Equip. Co., Chicago, IL). Seed weight was determined after counting seeds using the Agriculex electronic seed counter model ESC-1 (Agriculex Inc., Guelph, Ont., Canada). Grain yield was converted to $15.5 \%$ moisture content. Additionally, weather data (air temperature and precipitation) were recorded during soybean vegetation using a weather station located near the experimental site.

\subsection{Statistical Analysis}

The study design was a Randomized Complete Block with eight replications. Data were analyzed using the general linear models in SAS (2011) by analysis of variance and means were separated using Fisher's Least Significant Difference Test at $p \leq 0.05$. A linear regression model was fit using PROC REG (SAS, 2011) after contrast analyses indicated a significant $(\mathrm{p} \leq 0.05)$ response. 


\section{RESULTS}

\subsection{Weather Conditions}

Monthly average temperature, precipitation and average from the 30-yr average are shown in Table 1. The average monthly air temperature was generally similar to 30-yr average, except for June and July 2011 and August 2012 when temperature was 2.3, 1.3 and $1.1^{\circ} \mathrm{C}$ higher and October 2011 and June 2012 when temperature was 2.3 and $1.4^{\circ} \mathrm{C}$ lower than $30-\mathrm{yr}$ average, respectively.

Precipitation was $151 \mathrm{~mm}$ higher during soybean growing season in 2011 and $15 \mathrm{~mm}$ higher in 2012 than 30-yr average (Table 1). Insufficient precipitation was observed in June in two soybean growing seasons and also July, September and October in 2012. Compared to multiyear rainfall data, higher precipitation was recorded in August in 2011 and 2012 and July, September and October in 2011.

\subsection{Plant Leaf Area Index (LAI) and Normalized Difference Vegetation Index (NDVI)}

Table 2 shows that plant LAI significantly increased by $22.8 \%$ with high rate of $\mathrm{P}$ at $90 \mathrm{~kg} \mathrm{ha}^{-1}$ and polymer Avail application to winter wheat previous crop compared to untreated control at 3 months after soybean planting. Applying $\mathrm{P}$ fertilizer at $45 \mathrm{~kg} \mathrm{ha}^{-1}$ with polymer Avail improved soybean LAI by $11.8 \%$ over control. Soybean LAI increased by $4.5 \%$ and $10.2 \%$ with $\mathrm{P}$ in combination with Avail applied at $45 \mathrm{~kg}$ and $90 \mathrm{~kg}$ $\mathrm{ha}^{-1}$ to winter wheat, respectively. Plant LAI was not significantly affected by treatment application at 2 months after soybean planting.

Compared to untreated control, treatment with $\mathrm{P}$ and polymer Avail applied to winter wheat previous crop significantly improved plant NDVI at 3 months after planting of soybean (Table 2). Plant NDVI increased by 1.8 and $2.5 \%$ over untreated control at 45 and $90 \mathrm{~kg} \mathrm{P}$ $\mathrm{ha}^{-1}$ with polymer Avail. Phosphorus and Avail applications to winter wheat did not affect soybean NDVI at 2 months after planting soybeans.

\subsection{Plant Height, Grain Moisture, Seed Weight and Grain Yield}

Compared to the untreated control, application of $\mathrm{P}$ with polymer Avail to winter wheat previous crop significantly improved grain yields of following soybean crop (Table 3). Soybean yields increased by $12.3 \%$ over untreated control with $\mathrm{P}$ rate of $45 \mathrm{~kg} \mathrm{ha}^{-1}$ and Avail applied to winter wheat and $20.2 \%$ at $\mathrm{P}$ rate of $90 \mathrm{~kg} \mathrm{ha}^{-1}$ with Avail compared to control. Compared to $\mathrm{P}$ fertilizer without Avail, addition of Avail to $\mathrm{P}$ improved soybean yields by 8.1 and $4.0 \%$ with $45 \mathrm{~kg}$ and $90 \mathrm{~kg} \mathrm{P}^{-1}$ applied to wheat previous crop. Plant height, grain moisture and seed weight of soybeans were not significantly affected by $\mathrm{P}$ with polymer Avail applications to winter wheat previous crop.

Table 1. Monthly average air temperature and precipitation during soybean growth near Blackville, SC from 2011 to 2012

\begin{tabular}{|c|c|c|c|c|c|c|}
\hline \multirow[b]{2}{*}{ Year } & \multicolumn{5}{|c|}{ Month } & \multirow[b]{2}{*}{ Average/total } \\
\hline & June & July & Aug. & Sep. & Oct. & \\
\hline \multicolumn{7}{|c|}{ Temperature $\left({ }^{\circ} \mathrm{C}\right)$} \\
\hline 2011 & 27.4 & 28.0 & 18.0 & 23.2 & 15.9 & 21.3 \\
\hline 2012 & 23.8 & 27.7 & 18.8 & 22.7 & 18.4 & 21.9 \\
\hline $30-y r$ avg. & 25.2 & 26.8 & 17.8 & 23.4 & 18.2 & 21.6 \\
\hline \multicolumn{7}{|c|}{ Precipitation (mm) } \\
\hline 2011 & 58.0 & 140.0 & 182.0 & 142.0 & 111.0 & 575.0 \\
\hline 2012 & 80.0 & 97.0 & 309.0 & 19.0 & 14.0 & 439.0 \\
\hline $30-y r$ avg. & 129.0 & 130.0 & 122.0 & 92.0 & 80.0 & 524.0 \\
\hline
\end{tabular}

Table 2. Influence of Phosphorus (P) and Avail applied to winter wheat previous crop on soybean Leaf Area Index (LAI) and Normalized Difference Vegetation Index (NDVI) at 2 and 3 months after planting near Blackville, SC from 2011 to 2012.

\begin{tabular}{|c|c|c|c|c|}
\hline \multirow[b]{2}{*}{$\mathrm{P}$ rate $\left(\mathrm{kg} \mathrm{ha}^{-1}\right)$} & \multicolumn{2}{|c|}{$\begin{array}{l}\text { Leaf Area Index (LAI) } \\
\text { (months after planting) }\end{array}$} & \multicolumn{2}{|c|}{$\begin{array}{l}\text { Normalized Difference Vegetation Index } \\
\text { (NDVI) (months after planting) }\end{array}$} \\
\hline & 2 & 3 & 2 & 3 \\
\hline Control & 2.90 & 4.97 & 0.6085 & 0.8830 \\
\hline 45 & 3.05 & 5.36 & 0.6593 & 0.8991 \\
\hline 45+Avail & 3.07 & 5.60 & 0.6478 & 0.8995 \\
\hline 90 & 3.16 & 5.69 & 0.6279 & 0.8997 \\
\hline 90+Avail & 3.22 & 6.27 & 0.6357 & 0.9057 \\
\hline $\operatorname{LSD}_{(0.05)}$ & NS & 0.90 & NS & 0.0145 \\
\hline
\end{tabular}


Table 3. Influence of Phosphorus $(\mathrm{P})$ and Avail applied to winter wheat previous crop on plant height, grain moisture, weight of 100 seeds and grain yield of soybeans near Blackville, SC from 2011 to 2012

\begin{tabular}{|c|c|c|c|c|}
\hline $\begin{array}{l}\mathrm{P} \text { rate }\left(\mathrm{kg} \mathrm{ha}^{-1}\right) \\
\left.\mathrm{ha}^{-1}\right)\end{array}$ & Plant height $(\mathrm{cm})$ & Grain moisture (\%) & 100 seed weight (gms) & Grain yield \\
\hline Control & 85.5 & 12.5 & 12.9 & 1.87 \\
\hline 45 & 85.5 & 12.6 & 13.5 & 2.10 \\
\hline $45+$ Avail & 83.4 & 12.9 & 13.2 & 2.27 \\
\hline 90 & 86.9 & 12.8 & 13.6 & 2.23 \\
\hline $90+$ Avail & 84.7 & 12.3 & 13.1 & 2.32 \\
\hline $\operatorname{LSD}_{(0.05)}$ & NS & NS & NS & 0.22 \\
\hline
\end{tabular}

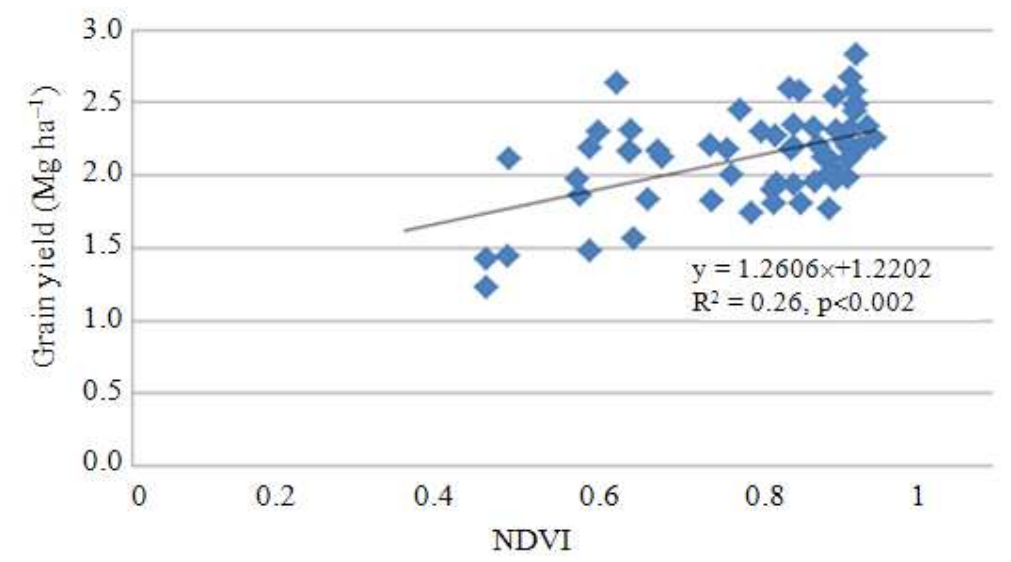

Fig. 1. Relationship between plant Normalized Difference Vegetation Index (NDVI) at 2 months after planting and grain yield of soybeans from 2011 to 2012

\subsection{Relationships between Grain Yields and Plant NDVI}

A significant relationship was observed between grain yield and plant NDVI at 2 months following soybean planting (Fig. 1). Based on this linear relationship, increasing plant NDVI by 0.1 at 3 month after planting soybeans increased grain yields by $126.1 \mathrm{~kg} \mathrm{ha}^{-1}$.

\section{DISCUSSION}

Previous research was limited and not conclusive. According to De Figueiredo et al. (2012), polymercoated P improved plant height of corn compared to standard $\mathrm{P}$ application. However, this study showed no effect of coated $P$ with polymer Avail on soybean height. Plant LAI and NDVI generally improved with $\mathrm{P}$ and polymer Avail applications to winter wheat previous crop. Applying P at $45 \mathrm{~kg}$ and $90 \mathrm{~kg} \mathrm{P} \mathrm{ha}^{-1}$ with polymer Avail to wheat previous crop increased soybean LAI by 4.5 and $10.2 \%$ over uncoated $\mathrm{P}$, respectively at 3 months after planting. Plant NDVI at 3 months after soybean planting improved with $\mathrm{P}$ and polymer Avail applied to previous crop at $45 \mathrm{~kg}$ and $90 \mathrm{~kg} \mathrm{P} \mathrm{ha}{ }^{-1}$ by $1.8 \%$ and $2.5 \%$ over control, respectively.

Previous studies showed that corn grain yields were not affected by P fertilization (Kolawole, 2012) and wheat grain yields did not significantly improve with application of Monoammonium Phosphate (MAP) coated with Avail compared to uncoated MAP (Karamanos and Puurveen, 2011). However, De Figueiredo et al. (2012) reported higher corn yields with the polymer-coated MAP over conventional MAP. In the study conducted by Kamara et al. (2012), application of $\mathrm{P}$ fertilizer increased pod number per plant, which contributed to increased soybean yields. Kamara et al. (2012) recommended applying $40 \mathrm{~kg} P$ $\mathrm{ha}^{-1}$ to optimize soybean production. Liu et al. (2010) reported that no $\mathrm{P}$ application reduced soil $\mathrm{P}$, but applying high $\mathrm{P}$ fertilizer rate at $80 \mathrm{~kg} \mathrm{ha}^{-1}$ increased soybean yields. Zheng et al. (2010) reported that soybean yields increased with $\mathrm{P}$ application rate of up to $55.67 \mathrm{~kg} \mathrm{ha}^{-1}$. In this study, applying $45 \mathrm{~kg}$ and 90 $\mathrm{kg} \mathrm{P} \mathrm{ha}{ }^{-1}$ with polymer Avail to winter wheat previous crop increased soybean yields by 8.1 and $4.0 \%$ over uncoated $\mathrm{P}$, respectively. Compared to untreated control, grain yields of soybean increased by 12.3 and $20.2 \%$ with applying $45 \mathrm{~kg}$ and $90 \mathrm{~kg} \mathrm{P}$ $\mathrm{ha}^{-1}$ with polymer Avail to previous wheat crop, respectively. Based on linear relationship, increasing plant NDVI by 0.1 increased soybean yields by 126.1 $\mathrm{kg} \mathrm{ha}{ }^{-1}$. It agrees with Raun et al. (2001), who reported a strong relationship between plant NDVI and yields of winter wheat. 


\section{CONCLUSION}

This study investigated the effect of two $\mathrm{P}$ rates (45 and $90 \mathrm{~kg} \mathrm{P}_{2} \mathrm{O}_{5} \mathrm{ha}^{-1}$ ) with and without Avail applied to winter wheat previous crop on growth and yield of following soybeans crop grown under dryland conditions. Application of $90 \mathrm{~kg} \mathrm{P} \mathrm{ha}{ }^{-1}$ with polymer Avail to winter wheat previous crop increased soybean LAI at 3 months after planting by $22.8 \%$ over untreated control. Application of lower P rates at $45 \mathrm{~kg} \mathrm{ha}^{-1}$ with Avail to winter wheat improved soybean LAI by $11.8 \%$. Addition of polymer Avail to $45 \mathrm{~kg}$ and $90 \mathrm{~kg} \mathrm{P}$ $\mathrm{ha}^{-1}$ to winter wheat previous crop increased soybean LAI by 4.5 and $10.2 \%$ compared to $\mathrm{P}$ rates without polymer Avail, respectively. Plant NDVI improved by $1.8 \%$ and $2.5 \%$ over control at 3 months after soybean planting with $45 \mathrm{~kg}$ and $90 \mathrm{~kg} \mathrm{P} \mathrm{ha}{ }^{-1}$ in combination with polymer Avail applied to winter wheat previous crop, respectively. Compared to untreated control, soybean yields increased by 12.3 and $20.2 \%$ with $45 \mathrm{~kg}$ and $90 \mathrm{~kg} \mathrm{P} \mathrm{ha}^{-1}$ and polymer Avail applied to previous wheat crop, respectively. Compared to $45 \mathrm{~kg}$ and $90 \mathrm{~kg}$ $\mathrm{P} \mathrm{ha}{ }^{-1}$ without Avail, coating $\mathrm{P}$ with Avail increased soybean yields by 8.1 and $4.0 \%$, respectively. A significant positive linear relationship showed that increasing plant NDVI by 0.1 increased crop yield by $126.1 \mathrm{~kg} \mathrm{ha}^{-1}$. Application of $\mathrm{P}$ and polymer Avail to winter wheat previous crop did not affect soybean LAI and NDVI at 2 months after planting, plant height, grain moisture and seed weight. Generally, grain yield of soybeans increased due to improved plant LAI and NDVI with $\mathrm{P}$ and polymer Avail applications to winter wheat previous crop. Future research may evaluate application of $\mathrm{P}$ with Avail to wheat previous crop on following soybeans under irrigation system.

\section{ACKNOWLEDGEMENT}

I greatly appreciate a financial support from Specialty Fertilizer Products (SFP) for conducting field research.

\section{REFERENCES}

Abbasi, M.K., M. Manzoor and M.M. Tahir, 2010. efficiency of Rhizobium inoculation and $p$ fertilization in enhancing nodulation, seed yield, and phosphorus use efficiency by field grown soybean under hilly region of Rawalakot Azad Jammu and Kashmir, Pakistan. J. Plant Nutr., 33: 1080-1102. DOI: 10.1080/01904161003729782

Abbasi, M.K., M.M. Tahir, W. Azam, Z. Abbas and N. Rahim, 2012. Soybean yield and chemical composition in response to phosphorus-potassium nutrition in Kashmir. Agron. J., 104: 1476-1484. DOI: 10.2134 /agronj2011.0379
Anthony, P., G. Malzer, M.C. Zhang and S. Sparrow, 2012. Soil nitrogen and phosphorus behavior in a long-term fertilization experiment. Agron. J., 104: 1223-1237. DOI: 10.2134/agronj2012.0020

De Figueiredo, C.C., D.V. Barbosa, S.A. de Oliveira, M. Fagioli and J.H. Sato, 2012. Polymer-coated phosphate fertilizer and liming on the production and morphological parameters of corn. Rev. Cienc. Agron., 43: 446-452. DOI: 10.1590/S180666902012000300005

Guareschi, R.F., P.R. Gazolla, A. Perin and J.M.K. Santini, 2011. Antecipated fertilization on soybean with triple superphosphate and potassium chloride coated with polymers. Cienc. Agrotec., 35: 643-648. DOI: $10.1590 / \mathrm{S} 1413-70542011000400001$

Hassan, H.M., P. Marschner, A. McNeill and C. Tang, 2012. Grain legume pre-crops and their residues affect the growth, $\mathrm{P}$ uptake and size of $\mathrm{P}$ pools in the rhizosphere of the following wheat. Biol. Fert. Soils, 48: 775-785. DOI: 10.1007/s00374-0120671-8

Kamara, A.Y., F. Ekeleme, L.O. Omoigui and H.A. Ajeigbe, 2012. Phosphorus and nitrogen fertilization of soybean in the Nigerian Savanna. Exp. Agric., 48: 39-48. DOI: $10.1017 / \mathrm{s} 0014479711000512$

Karamanos, R.E. and D. Puurveen, 2011. Evaluation of a polymer treatment as enhancer of phosphorus fertilizer efficiency in wheat. Can. J. Soil Sci., 91: 123-125. DOI: 10.4141/cjss10071

Kihara, J., B. Vanlauwe, B. Waswa, J.M. Kimetu and J. Chianu et al., 2010. Strategic phosphorus application in legume-cereal rotations increases land productivity and profitability in Western Kenya. Exp. Agric., 46: 35-52. DOI: 10.1017/s0014479709990810

Kolawole, G.O., 2012. Effect of phosphorus fertilizer application on the performance of maize/soybean intercrop in the southern Guinea Savanna of Nigeria. Arch. Agron. Soil Sci., 58: 189-198. DOI: 10.1080/03650340.2010.512723

Liu, J., K. Cai, S. Luo, L. Zhu and J. Zhang et al., 2010. Soil phosphorous status and phosphorus cycling as influenced by soybean genotypes on an acidic lowphosphorus soil of Southern China. Commun. Soil Sci. Plant Anal., 41: 1838-1849. DOI: 10.1080/00103624.2010.492441

McBeath, T.M., M.J. McLaughlin and S.R. Noack, 2011. Wheat grain yield response to and translocation of foliar-applied phosphorus. Crop Pasture Res., 62: 58-65. DOI: $10.1071 / \mathrm{cp} 10237$ 
McBeath, T.M., M.J. McLaughlin, J.K. Kirby and R.D. Armstrong, 2012. The effect of soil water status on fertiliser, topsoil and subsoil phosphorus utilisation by wheat. Plant Soil, 358: 337-348. DOI: 10.1007/s11104-012-1177-8

McLaughlin, M.J., T.M. McBeath, R. Smernik, S.P. Stacey and B. Ajiboye et al., 2011. The chemical nature of $\mathrm{p}$ accumulation in agricultural soilsimplications for fertiliser management and design: An Australian perspective. Plant Soil, 349: 69-87. DOI: $10.1007 / \mathrm{s} 11104-011-0907-7$

Noack, S.R., M.J. McLaughlin, R.J. Smernik, T.M. McBeath and R.D. Armstrong, 2012. Crop residue phosphorus: Speciation and potential bioavailability. Plant Soil, 359: 375-385. DOI: 10.1007/s11104-012-1216-5

Nunes, R.D., D.M.G. de Sousa, W.J. Goedert and L.J. Vivaldi, 2011. Phosphorus distribution in soil as affected by cropping systems and phosphate fertilization management. Rev. Bras. Cienc. Solo, 35: 877-888. DOI: 10.1590/S0100-06832011000300022

Olibone, D. and C.A. Rosolem, 2010. Phosphate fertilization and phosphorus forms in an oxisol under no-till. Sci. Agric., 67: 465-471. DOI: 10.1590/s0103-90162010000400014

Qiao, S.M.Y., 2012. Distribution of inorganic and organic phosphorus fractions in two phosphorusdeficient soils as affected by crop species and nitrogen applications. Commun. Soil Sci. Plant Anal., 43: 631-644. DOI: $10.1080 / 00103624.2012 .644004$
Raun, W.R., J.B. Soile, G.V. Johnson, M.L. Stone and E.V. Lukina et al., 2001. In-season prediction of potential grain yield in winter wheat using canopy reflectance. Agron. J., 93: 131-138. DOI: 10.2134/agronj2001.931131x

Rehm, G.W. and J. Lamb, 2010. Soybean response to fluid fertilizers placed near the seed at planting. Soil Sci. Soc. Am. J., 74: 2223-2229. DOI: 10.2136/sssaj2009.0442

SAS, 2011. SAS/STAT® 9.3 User's Guide. SAS Institute Inc., Cary, NC.

Steiner, F., L.A. Pivetta, G. Castoldi, M.S.S.M. Costa and L.A.M. Costa, 2012. Phosphorus and potassium balance in soil under crop rotation and fertilization. Semina-Ciencias Agrarias, 33: 2173-2186. DOI: 10.5433/1679-0359.2012v33n6p2173

Yang, Y., Z. He, X. Yang, J. Fan, P. Stoffella and C. Brittain, 2012. Dolomite phosphate rock-based slow-release fertilizer for agriculture and landscapes. Commun. Soil Sci. Plant Anal., 43: 1344-1362. DOI: 10.1080/00103624.2012.666308

Zheng, H., L. Chen, X. Han, Y. Ma and X. Zhao, 2010. Effectiveness of phosphorus application in improving regional soybean yields under drought stress: A multivariate regression tree analysis. Afr. J. Agric. Res., 5: 3251-3258. 